\title{
Dossiê
}

Dramaturgia Musical

Ópera coreográfica: experiência e possibilidades para dramaturgias do corpo

Paulo Maron, Diósnio Machado Neto e Marília Velardi 


\section{Ópera coreográfica: experiência e possibilidades para dramaturgias do corpo}

\section{Paulo Maron}

(Diretor da companhia NUO-Ópera Laboratório; Doutorando do Programa de Pós-Graduação em Música da ECA-USP); paulomaron@usp.br

Diósnio Machado Neto

(ECA-USP; coordenador do Laboratório de Musicologia da USP-LAMUS);

Marília Velardi

(EACH-USP; coordenadora do Grupo de Estudos em Corpo e Arte-ECOAR).

Resumo: Esse artigo discorre sobre a ideia de Ópera coreográfica como prática artística presente no escopo das dramaturgias do corpo e, para isso, partimos das reflexões suscitadas pelas montagens coreográficas de óperas realizadas por diversos coreógrafos para, posteriormente, trazermos as posições do historiador e crítico David Levin e algumas posições de Meyerhold sobre a encenação e a performance em ópera. Como mediadora dessas reflexões, trazemos nossa experiência na concepção e apresentação da nossa versão coreográfica para a ópera Prometheus, de Gabriel Fauré, encenada e apresentada na cidade de São Paulo por uma companhia independente de ópera-laboratório.

Palavras-chave: Ópera; ópera coreográfica; corpo; dança; canto lírico.

Abstract: This paper discusses the idea of choreographic opera as an artistic practice present in the scope of the body dramaturgy and, for that, we set the reflections raised by the choreographies of operas performed by some coreographers. Later, we bring the positions of the historian and critic David Levin and some positions from Meyerhold about staging opera. As mediators of these reflections we bring our experience in the conception and performance of our version choreographic for Prometheus (Gabriel Fauré), staged and presented in São Paulo by an opera-lab company.

Keywords: opera; choreographic opera; dance; body; lyrical singing.

Em 2011 decidimos coreografar uma ópera. Diferente dos referenciais que já tínhamos visto, a nossa ideia era coreografá-la integralmente e coreografá-la não apenas como recurso de marcação de cena ou de incorporação de gestual, mas, de fato, inscrever a dramaturgia no corpo e a partir dela chegar ao texto e à música. Nós sabíamos que os nossos artistas, os cantores líricos-atores, poderiam fazer isso. Na verdade, ao longo de sete anos de existência da nossa companhia a preparação corporal centrada na Educação Somática e na Dança nos mostrava nos ensaios uma poética viva e pulsante. Levar aquilo que era feito na preparação para a cena aberta ao público, como matéria e como forma de uma montagem, era só uma questão de tempo. Mergulhamos na ideia da ópera coreográfica.

A expressão ópera coreográfica é utilizada pela artista alemã Sasha Waltz, que num de seus mais importantes projetos assume essa ideia: em Entwicklung der choreographis- 
chen Oper (Desenvolvimento da Ópera coreográfica) ela busca promover um novo tipo de diálogo entre a música, a dança e o teatro no qual coralistas e solistas fazem parte de uma coreografia global, dissociando-os das suas funções originais. Esse é um projeto que conta com diversos espetáculos produzidos, dentre os quais Dido e Aeneas de Purcell que estreou em 2005, Medea com música de Pascal Dusapin (2007), o poema sinfônico Romeu e Julieta de Berlioz (2007); seguem Passion (2010) de Pascal Dusapin e Matsukaze (2011) composição de Toshio Hosokawa. Em 2014 Sasha Waltz voltou a explorar a ópera barroca com a sua montagem para Orfeu, de Claudio Monteverdi (Waltz, 2016).

Assim como nas concepções de Sasha Waltz a ópera foi coreografada por outros importantes artistas: em 1936, Georges Balanchine escandalizou o Metropolitan Opera House com uma ousada montagem coreográfica para Orfeu e Eurídice de Gluck, obra que 40 anos depois foi coreografada por Pina Bausch estreando em Wuppertal. Seguiram, em 1989, Mark Morris e sua coreografia para Dido e Aeneas de Gluck e Trisha Brown e sua concepção e direção para Orfeu de Monteverdi em 1998. Nos anos 2000 Bob Wilson, mesmo não sendo coreógrafo, coreografou a versão de Berlioz para o Orfeu e Eurídice de Gluck e, anos mais tarde Mats Ek fez também a sua versão para a mesma obra (Levin, 2001).

De modo radical, em 2003, o britânico Yinka Shonibare filmou a sua versão para Um baile de máscaras de Verdi, coreografado por Faustin Linyekula. Posicionando-se politicamente, $\mathrm{o}$ artista propõe a retirada da música na última cena da ópera, no seu momento culminante. A ideia da cena pressupõe uma música internalizada, em que a coreografia é elemento cênico indispensável para a dramaturgia. A música está como partitura encarnada nas ações e coreografias dos atores. A versão de Shonibare trouxe inúmeras reflexões no meio acadêmico, não só pela ousadia de subverter a música à coreografia, mas porque o artista propõe, na sua concepção, uma reflexão importante sobre a arte como resistência ao colonialismo e a natureza clássica dos hibridismos artísticos (Morris, 2014).

Nota-se que há um predomínio importante de óperas barrocas quando toda a encenação é coreografada. Esse uso das óperas barrocas como opção para uma exploração coreográfica do gênero provavelmente deve-se ao fato de que as óperas concebidas nesse período trazem uma dramaturgia alegórica, muitas vezes mitológica, o que tende a ampliar as possibilidades cênicas. Musicalmente essas óperas apresentam transparência vocal e do instrumental, sem a grandiosidade característica dos períodos subsequentes - classicismo e romantismo. Mais do que isso, em relação a sua forma, a ópera barroca apresenta, além de recitativos e árias, uma gama de trechos instrumentais que permitiriam uma melhor articulação com os elementos coreográficos.

É de certo modo irônico pensar que, se na atualidade é a ópera barroca aquela que tem sido mais usada no anúncio de novas tessituras música-teatro-dança como forma de incorporação entre os gêneros, no período barroco o ballet era considerado nada mais do que elemento de adorno da estrutura da ópera. No século XIX o ballet era incluído nas óperas em seu segundo ou terceiro atos, em pontos culminantes da ação dramatúrgica. Os trechos instrumentais entre as cenas eram previstos na escritura das partituras, ou seja, faziam parte da forma musical e era praticamente impensável uma ópera (como forma) composta sem a inclusão de um ballet emoldurando as narrativas musicais. 
Essa lógica formal em relação à inclusão do ballet remonta ao surgimento da ópera no período barroco. É na ópera francesa deste período, mais especificamente nas composições de Jean Baptiste Lully, que o espaço do ballet estrutura a forma musical do gênero. Antes de escrever óperas, Lully foi responsável pela composição de inúmeros ballets para a corte do Rei Luiz XIV, o que certamente o influenciou a inserir a música para os ballets quando das suas primeiras óperas. Com o tempo isso passou a ser uma tradição para a ópera francesa.

Se o período barroco marcou o surgimento da ópera como um gênero que poderia trazer à luz o teatro grego, não tardou para, no mesmo período, a ideia de ópera como gênero musical ser fortalecida, algo que parece persistir até hoje. No entanto, embora na atualidade haja certo consenso de que a ópera é parte do escopo da prática musical é também comum considera-la como um gênero de certo modo híbrido. Gesamtkunstwerk é, em geral, o termo associado a esse hibridismo, talvez utópico, quando são buscadas referências que permitam afirmar que a ópera é mais do aquilo que pode ser abarcado pelo gênero musical. Esse termo é geralmente traduzido como uma alusão à ideia de cooperação entre diversas artes na realização de um espetáculo teatral e, provavelmente por ter sido cunhado por Richard Wagner, é utilizado como a síntese do que é (ou deveria ser utopicamente) o gênero idealizado pelo compositor: o drama musical que, amparado pela colaboração entre diversas artes, daria sentido ao que fora escrito por ele e permitiria a exacerbação da ideia de drama (Wagner, 1995; Dudeque, 2009).

Apesar de propor o sentido de colaboração entre as artes, a dança (naquele período o ballet) só aparece como elemento essencial para o drama wagneriano em Tannhäuser. Na estreia da ópera em Dresden em 1845, Wagner levou ao palco a sua versão original sem o tradicional espaço para o ballet que fora formalizado no período barroco. A oposição inicial de Wagner ao uso do ballet na ópera não se relacionava ao fato de ele considera-la uma arte menor, mas o modo como as danças eram normalmente inseridas, interrompendo a dramaturgia e utilizadas como adornos da cenas era, de fato, aquilo que o incomodava.

Na estreia de Tannhäuser na França no ano de 1861, o Imperador Napoleão III recebeu um pedido da Princesa Pauline Von Metternich, esposa do embaixador da Áustria na França: ela sugeriu que Wagner incluísse um ballet para a exibição da ópera em Paris. $\mathrm{O}$ receio dela era que, uma vez que para os franceses uma ópera sem ballet não se constituía como tal, a sua ausência pudesse esvaziar o teatro.

A dramaturgia de Tannhäuser não pedia um ballet, mas, motivado talvez por razões políticas, Wagner o incluiu. Tanhäuser já estava escrita e Wagner não se permitiria, por ser também o libretista, a ferir a sua dramaturgia. $\mathrm{O}$ ballet foi, então, inserido na abertura da ópera.

Se por um lado Wagner recusou-se a modificar a dramaturgia, por outro ele reescreveu a partitura da abertura para incluir algo que pudesse ampliar e enriquecer o seu sentido. A narrativa coreográfica do templo de Vênus não foi um adorno arranjado como ocorria até então, mas uma representação visceral daquilo que estava apenas no texto e na partitura. Talvez essa tenha sido uma das primeiras iniciativas formais de associação do ballet como elemento cênico indispensável para a dramaturgia na ópera. Nessa abertura, 
no templo de Vênus, a ação dramática traduzida como emoção localizou-se nos corpos dos dançarinos, ampliando o sentido do drama, daquilo que não poderia ser narrado.

Desde a sua criação o trecho do ballet em Tannhäuser tem sido coreografado por importantes figuras da dança mundial. Na recente versão apresentada pelo Berlin Staatsoper em 2014 a alemã Sasha Waltz foi convidada para coreografar a cena do templo de Vênus (Boccanegra, 2014). No entanto, historiadores afirmam que foi Maurice Bejárt, no ano de 1961, quem trouxe um novo sentido para a coreografia ao incorporar a personagem principal para o centro da cena: Tannhäuser deixou de ser um espectador que observava o que ocorria no templo de Vênus e, integrado à coreografia, entregou-se à sensualidade prevista pela música de Wagner. Na concepção de Bejárt o protagonista, que em geral ficava fora da cena coreográfica foi também integrante dela (Carnegy, 2006).

A resistência de Wagner à inserção do ballet na ópera talvez tenha trazido para a relação dança-ópera a sua maior contribuição. Se a única exceção em toda a sua obra aconteceu em Tannhäuser, aquilo que ele propôs para o drama musical parece ter desencadeado um vínculo estreito entre a dança e a dramaturgia.

Talvez esteja em Meyerhold a melhor descrição para o que poderia respaldar a concepção da ópera coreográfica:

Na encenação de Tristão e Isolda Meyerhold se inspira em Appia: a música é a substância da ação, é ela que, irracional, fala aos sentidos da alma, não ao intelecto, é a ação bem mais profunda. O encenador deve partir não do libreto, mas da partitura que fornece as soluções cênicas e de onde se desdobram os jogos de cena. A gestualidade do ator de ópera pode então ser assimilada a uma pantomima próxima da dança. Meyerhold escreve 'ali onde a palavra perde a sua força expressiva começa a linguagem da dança’. Ele busca a fusão do ritmo plástico com o ritmo musical, ele indica os graus de colaborações. Esses elementos correspondem, na percepção do público, a sensações de origens diversas, mas todas orientadas para um impacto idêntico e intensificadas por sua combinação harmônica (Picon-Vallin, 2013, p. 471).

Meyerhold declarou que a sua formação inicial em música foi decisiva para o seu desenvolvimento como diretor e pedagogo teatral. Se, por um lado o estudo da música o influenciou, por outro, muitas reflexões de Meyerhold sobre o teatro, o corpo do ator e a música foram sucitadas pela ópera wagneriana. Além disso, Meyerhold colaborou fortemente com compositores como Shostakovich, Prokofiev e Glazunov. Ele investiu nas colaborações com os compositores, pois almejava por algo que insistentemente lhe escapava: o desenvolvimento e a realização de uma nova ópera russa que encarnasse as suas ideias sobre a amálgama entre música, narrativa e movimento. Isso, segundo ele, seria a possibilidade de provar a viabilidade da ópera no século XX (Robinson, 1986). Sem dúvida a sua inserção nesse contexto, aliada às encenações de inúmeros títulos foram fundamentais para materializar as suas ideias de um ator-dançarino, de uma obra inteiramente conduzida pela música, internalizada ou não. Talvez fosse impossível com a ópera, e essa conclusão não veio sem uma crítica à imobilidade dos cantores de ópera em cena, como pode ser exemplificado quando se atribui a ele a crítica: 
Em Orfeu, a pantomina dos atores-dançarinos é sincrônica com a música e a homogeneidade plástica passa pelo desaparecimento dos coros cantados, invisíveis nas coxias: o palco inteiro se movimenta sem o hiato plástico da desarmonia imposta por um grupo de cantores estáticos (Picon-Vallin, 2013, p.472).

Disse Meyerhold que era melhor tirar os coralistas do palco, colocá-los nas coxias para não atrapalharem. E isso se fez, e isso assim se faz. Não é incomum que os cantores, especialmente nos coros, sejam substituídos por atores dançarinos. Nas montagens contemporâneas o que há de comum é o fato de que, mesmo quando realizadas as óepras coreográficas as montagens são protagonizadas, normalmente, por dois intépretes para cada persongem: um cantor e outro dançarino.

David Levin afirma que, nesses casos, os cantores passam a ser narradores da ação e é no corpo dos dançarinos que a emoção se mostra. Nessas montagens o corpo dos dançarinos é o lócus das emoções da ópera. Por sua vez, o lócus da cena (narrativa) se desloca ou se esconde na voz do cantor. Num período em que vivemos a era das imagens em alta definição o público se inquieta, pois ouvir não é mais suficiente: é preciso ver a voz, diz o autor (Levin, 2001).

Essa questão foi duramente criticada pela musicóloga Ellen Lockhart que afirmou que nas montagens contemporâneas, ainda que haja a procura por relações mais estreitas entre a ópera e a dança, isso ainda coloca a supremacia da técnica vocal sobre as ações cênicas e sobre a dança. Para a pesquisadora há um "efeito zumbi" entre cantores e dançarinos. O cantor, um narrador sem alma e o dançarino, um corpo distante sem narrativa (Morris, 2014; Schwartz, 2014; Schneidder, 2015). O paradoxo dessas montagens estaria, então, na ampliação da dicotomia entre o cantor e o dançarino, entre emoção e narrativa fragmentando e não amalgamando os sentidos possíveis da ópera.

Rupturas que promovam uma melhor articulação entre os elementos da ópera parecem ser, na atualidade, uma urgência. Se, por um lado, parece haver ainda certa resistência entre os tradicionalistas (incluam-se aí crítica, teatros, artistas e público), por outro, artistas e pesquisadores debruçam-se em busca de novas formas de realização. Na montagem de Sasha Waltz em 2014 para Orfeu, de Claudio Monteverdi, a coreógrafa passa a incorporar coralistas e solistas aos movimentos e dançarinos em trechos musicais.

A ópera coreográfica aparece como urgência também nos textos contemporâneos do historiador e crítico David Levin que traz nas suas discussões os conceitos que fundamentariam essa visão. Levin é um crítico contundente das montagens contemporâneas para o gênero. Segundo ele a potência da ópera se perde na medida em que o drama é concebido como uma obra completa (em relação a sua forma e seguindo o conceito wagneriano de Gesamtkunstwerk) e as suas expressões são geralmente baseadas nas interpretações psicanalíticas dos diretores sobre os temas irreais. Talvez, afirma Levin, a busca seja pela completude, mas a ópera entendida como a soma da partitura e libreto não está completa. Depende, para ser de fato Gesamtkunstwerk, daquilo que é feito no processo (Levin, 2001).

De quais modos, então, a possibilidade de formulação de uma ópera coreográfica poderia se configurar? 
Retomamos o início desse artigo, pois acreditamos que nós pudemos, de modo experimental, responder parcialmente a essa questão. Para nossa experiência na ópera coreográfica escolhemos a primeira ópera composta pelo francês Gabriel Fauré, com libreto de Jean Lorin e Ferdinand Hérold: Prometheu, que teve a sua estreia no ano de 1900, a céu aberto na Arènes de Beziéres para um público de 10.000 pessoas. Esta primeira versão foi composta para cem instrumentistas de cordas, quinze harpas e dois grupos de sopros (madeiras e metais), uma orquestração absolutamente diferente do estilo que caracterizou o compositor. Entre 1914 e 1916, Jean Roger-Ducasse, discípulo de Fauré, reorquestrou a partitura para uma orquestra reduzida (Phillips, 2011). Todavia, como não encontramos essa versão reorquestrada, decidimos fazê-la a partir da redução para piano e canto, para uma orquestra com instrumental menor: cordas, madeiras duplicadas, duas trompas, dois trombones, um trompete e par de tímpanos.

Essa nova orquestração deixou ainda mais evidente a influencia wagneriana na obra de Fauré. Por esse motivo encontramos na concepção do compositor um espaço para uma adaptação que julgamos fundamental para desenharmos a ideia de ópera coreográfica: as partes faladas em linguagem poética do texto original foram adaptadas para recitativos e para isso seguimos o estilo próprio de Fauré para as harmonias.

Considerando a dramaturgia apoiada no mito de Prometheus e levando em conta o período em que a obra foi encenada pela primeira vez, nós decidimos que partiríamos para a busca de uma coreografia que estivesse centrada na dramaturgia presente na partitura e que fosse estruturada com aquilo que Meyerhold nomeou de movimentos antinaturais.

Meyerhold afirmava que era preciso modificar a atmosfera das encenações em ópera. Como um arqueólogo ele escavou as camadas dos clichês dramáticos que haviam sido sobrepostos sobre a triangulação entre música, texto e ação. Meyerhold insistiu, então, que a ópera não deveria ser encenada partindo do libreto, tradição que vinha do verismo italiano e que perpetuou uma fatal contradição para o gênero: afinal de contas, dizia Meyerhold, ninguém canta na dinâmica da vida cotidiana. Para ele esse hiperrealismo só contribuía para que o público ficasse cada vez mais consciente da improbabilidade do gênero (Robinson, 1986).

Numa referência a sua montagem para Tristão e Isolda de Wagner, ele sintetizou:

Nesse espetáculo de ópera, que tende a uma ação sintética, em que se unem música, texto, dança, pintura, o cantor deve recusar tanto o gesto naturalista quanto o maneirismo e encontrar uma gestualidade artificial e rítmica, submetida ao desenho da partitura com uma precisão matemática. Ele precisa ter aulas com um mestre de ballet para traçar com o seu corpo desenhos plásticos capazes de destacar a música e de rematar um traço delineado pela orquestra, que vai no mesmo sentido que ele. Como o cenário que lhe é coarmônico, como a música que lhe é corítmica, o homem torna-se, ele mesmo, obra de arte, escreve Meyerhold (Picon-Vallin, 2013, p.472).

Na concepção para a montagem decidimos que a história mitológica aconteceria nos corpos dos nossos, agora, cantores-dançarinos. Para isso organizamos a preparação cor- 
poral em seis horas semanais e decidimos centrá-la na prática dos princípios da técnica de Martha Graham. Essa escolha baseou-se em duas razões fundamentais.

A primeira relacionada à influência que Martha Graham teve dos princípios de François Delsarte naquilo que ficou especialmente conhecido por delsartismo norte-americano (Armitage, 1978; Horosko, 2002). Pareceu-nos que recorrer àquelas formas e lógicas propostas por Delsarte levaría-nos àquilo que poderia ter inspirado as formas de expressão na estreia da Ópera em 1900, na França. Naquele momento a influência de Delsarte na formação dos cantores e atores era algo absolutamente natural.

A segunda razão foi o fato de que, embora quiséssemos algumas influências dos princípios delsartianos, nós buscávamos uma movimentação absolutamente irreal, não naturalizada. Não queríamos algo narrativo como estética. Não queríamos a humanização nem dos mitos gregos nem dos personagens "humanos". Além disso, queríamos levar os artistas a sentirem nos seus corpos aquilo que os movimentos trazem como sensações e percepções para que, a partir daí - e apenas a partir daí - eles começassem a estruturar as ações das suas personagens. A técnica de Martha Graham mostrava-se a escolha ideal.

Outra questão que também nos pareceu interessante foi resgatarmos as peças compostas por Martha Graham para aquilo que ficou reconhecido como o seu Ciclo Grego. No final dos anos 20 Martha Graham, como ela mesma afirmou, embarcou numa jornada pessoal na compreensão dos mitos gregos que, à luz da psicanálise, influenciariam sobremaneira a cultura e psique ocidental. Esse ciclo tem sido analisado academicamente e foi considerado como um momento importante para a criação de uma dança teatral norte-americana, levando Martha Graham a ser considerada não apenas uma personalidade da dança, mas uma artista teatral e uma das grandes intérpretes norte-americanas das tradições clássicas. Além disso, as peças do Ciclo Grego de Martha Graham trouxeram, especialmente nos anos 30 e 40, uma narrativa feminista para a cena; Medea, Ariadne, Jocasta, por exemplo, foram as mulheres-mitos trazidas à cena por Graham como condutoras das histórias e em torno das quais o drama se desenhava (Yaari, 2003).

$\mathrm{Na}$ nossa montagem, apesar de referir-se ao mito de Prometheus, ficava clara a importância central de quatro mulheres para a estruturação do drama: a Deusa Gaia, a titã Bia, a humana Aënoe e a primeira humana criada por Zeus, Pandora. O gestual próprio da técnica de Graham traz muitas vezes a tona a alternância entre a força e a delicadeza, $o$ abandono e a superação, a dor profunda e a expressão da vitalidade, e essas caraterísticas que se mostram claramente nas mulheres personagens do seu Ciclo Grego favoreceram a composição das mulheres personagens de Promtheus, para as quais um conjunto de elementos técnicos da técnica forneceram referenciais para as dinâmicas de movimentação e caracterização das personagens 


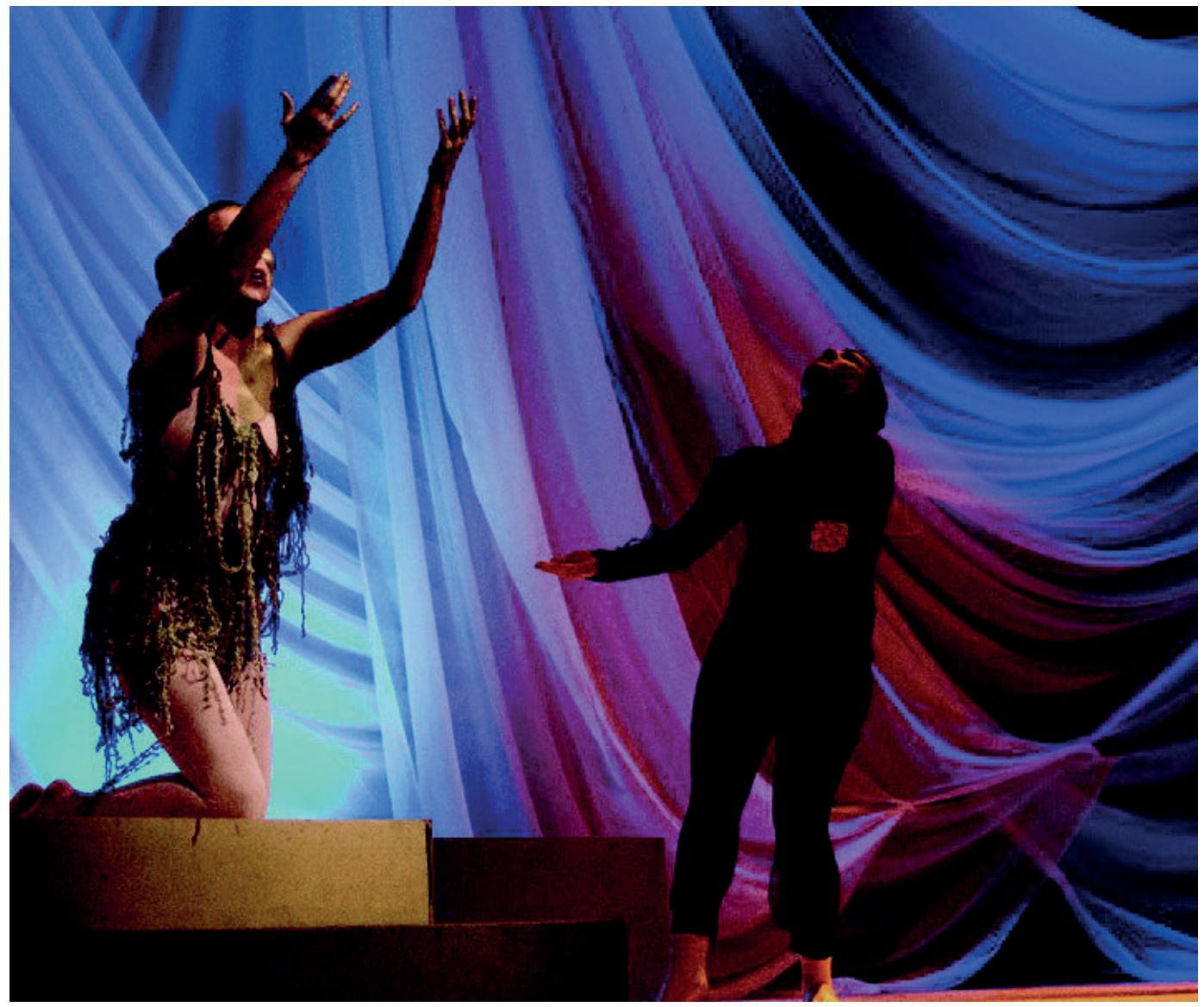

Pandora e Aënoe em cena da Ópera Prometheus de Gabriel Fauré encenada em São Paulo em julho de 2011. Teatro Anhembi-Morumbi. Fotografia de Karen Montija.

Para isso a preparação corporal centrada na técnica de Martha Graham pressupôs que os exercícios no solo (com ênfase nos trabalhos do tronco e o papel fundamental da respiração) e no centro tivessem como meta o treinamento de uma gama de movimentação e suas dinâmicas; e a tomada de consciência plena dos artistas sobre as sensações provocadas pelo tipo de movimentação: as mudanças de tônus determinadas pelas contrações e releases, a potência dos movimentos respiratórios, as pequenas contrações nas mãos, os pés absolutamente apoiados no solo mesmo durante os deslocamentos e uma relação profunda, sensível e colaborativa entre os corpos e o chão. Essas metas foram consideradas não apenas estruturantes do estilo ou das formas corporais, mas meios de estímulo às sensações e aos sentidos. Essa questão foi amplamente discutida nas fases de preparação e apresentação, tendo sido manifestada diversas vezes tanto nos ensaios quanto nas récitas. $\mathrm{Na}$ declaração de uma das artistas:

O que eu sinto é que Prometheus já é uma história muito forte, mas vivenciá-la antes no corpo, pela técnica de Martha Graham deixa tudo ainda maior, mais potente. Com os movimentos da técnica de Graham eu sinto intensificar sobremaneira minha concentração e envolvimento com a trama, primeiro por estarem em contato com o chão e os movimentos pesados e firmes, mas, sobretudo, pela importância da pelve e do tronco nessa movimentação. Acho maravilhoso e me emociono muito, sempre, tanto nas cenas em que estou, 


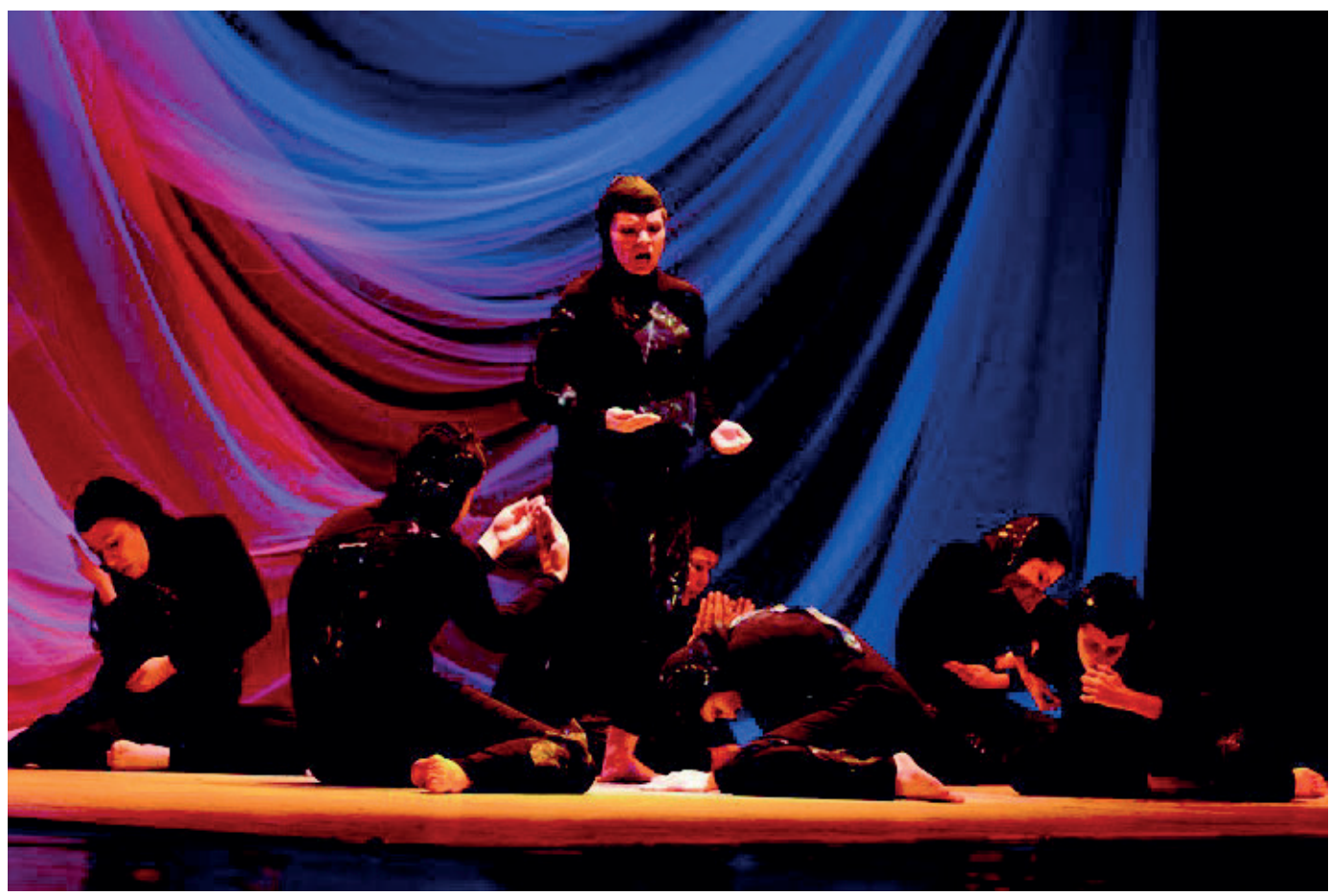

Coro feminino em cena da Ópera Prometheus de Gabriel Fauré encenada em São Paulo em julho de 2011. Teatro Anhembi-Morumbi. Fotografia de Karen Montija.

Ao longo dos ensaios o tempo dedicado à técnica de Martha Graham foi cedendo espaço à configuração de partituras corporais exploradas pelos artistas de modo que as sensações próprias pudessem orientar os movimentos e, progressivamente as ações corporais. Isso se deveu à nossa ideia mantermos firme aquilo que era a nossa meta primeira: a ópera inteiramente conduzida pela música e por uma dramaturgia inscrita no corpo, como propôs Meyerhold. Após um período de preparação técnica corporal e musical, a tarefa para cada artista foi compor e definir a sua partitura corporal articulada à partitura musical:

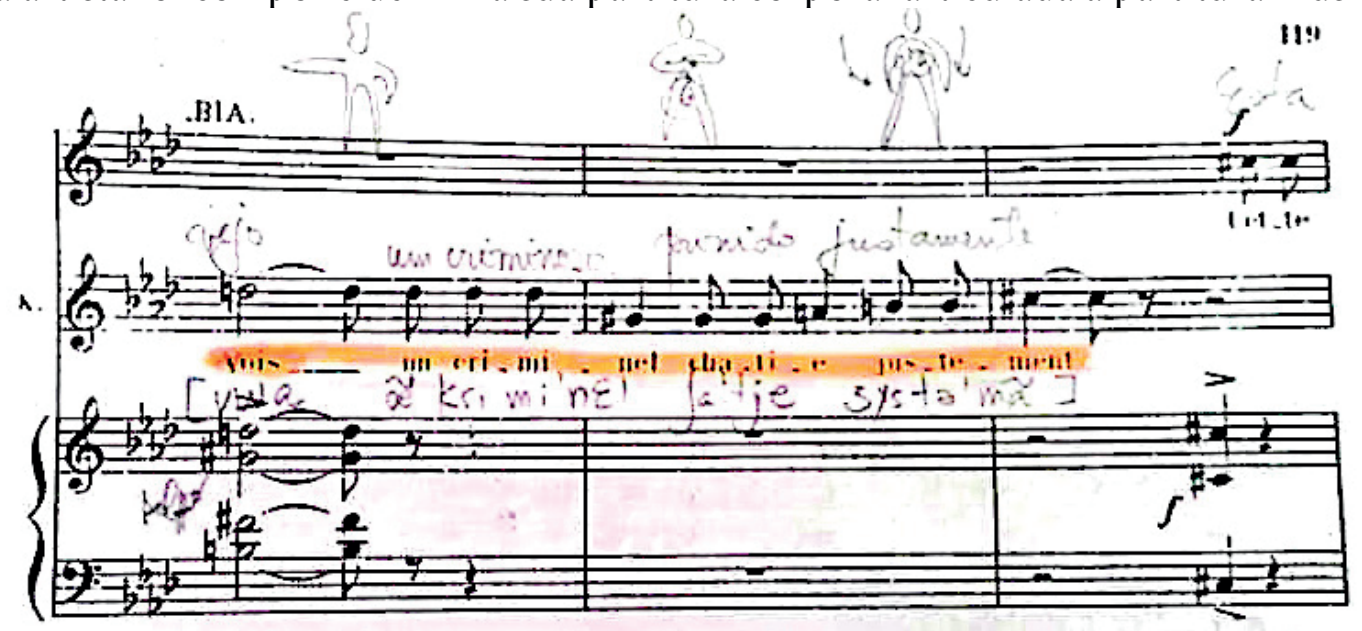

Exemplo de um trecho da partitura do personagem Kratos, protagonizado por André Estevez, na qual se pode ver uma pequena parte do exercício do artista na articulação partitura musical-partitura corporal. 


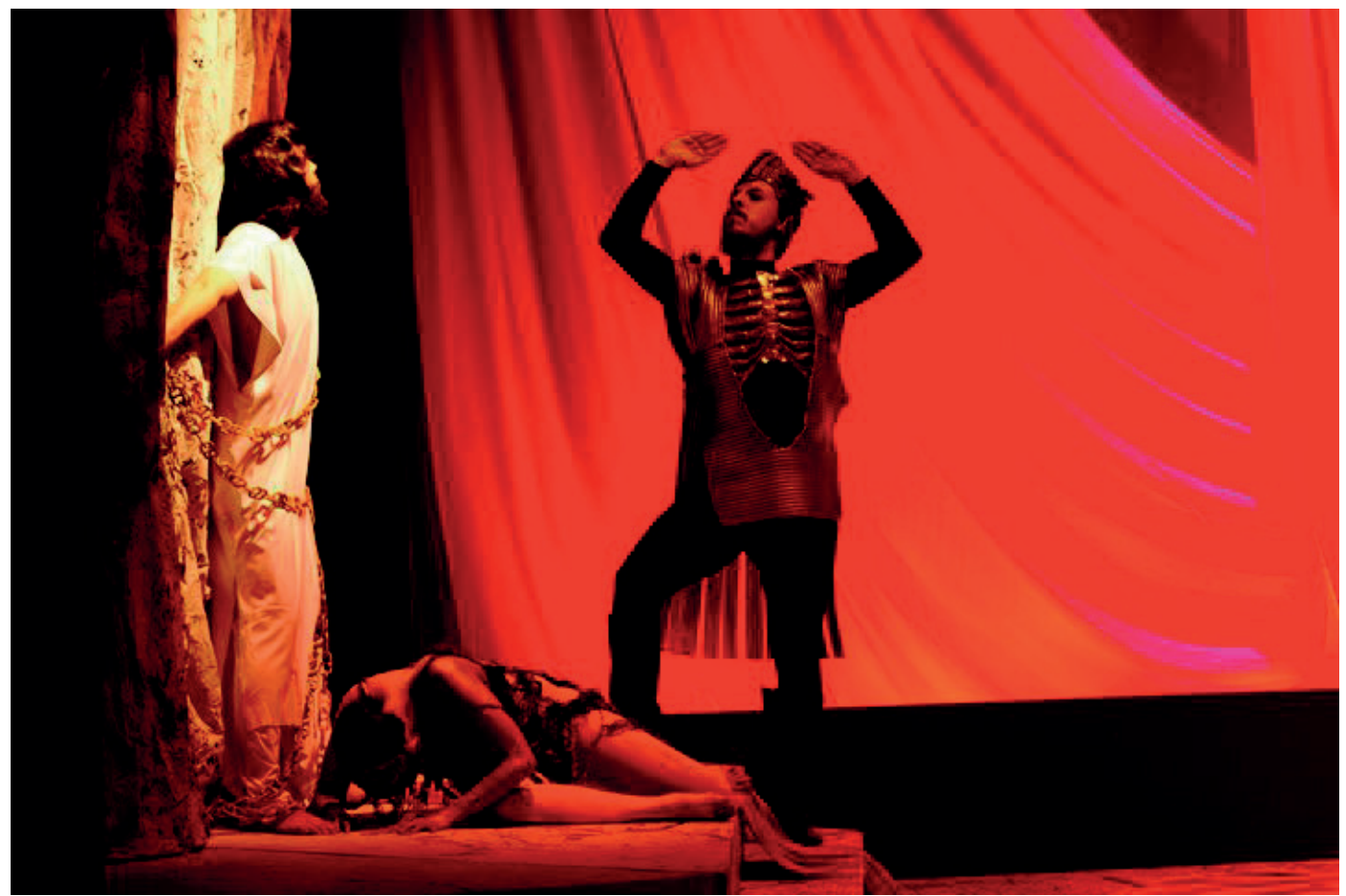

Prometheus, Pandora e Kratos em cena da Ópera Prometheus de Gabriel Fauré encenada em São Paulo em julho de 2011. Teatro Anhembi-Morumbi. Fotografia de Karen Montija

Em relação ao coro, as partituras corporais individuais foram também compostas e articuladas às partituras coletivas. Essas, por sua vez, foram sugeridas ora pelos artistas, ora propostas pela coreógrafa e pelo encenador. A organização da coreografia atendeu às considerações e solicitações entre grupo, coreógrafa e encenador. De modo geral, pode-se afirmar que a composição pressupôs uma interação importante entre todos os envolvidos na encenação e respondeu às características particulares das técnicas utilizadas durante a fase de preparação corporal que perdurou por quatro meses. 


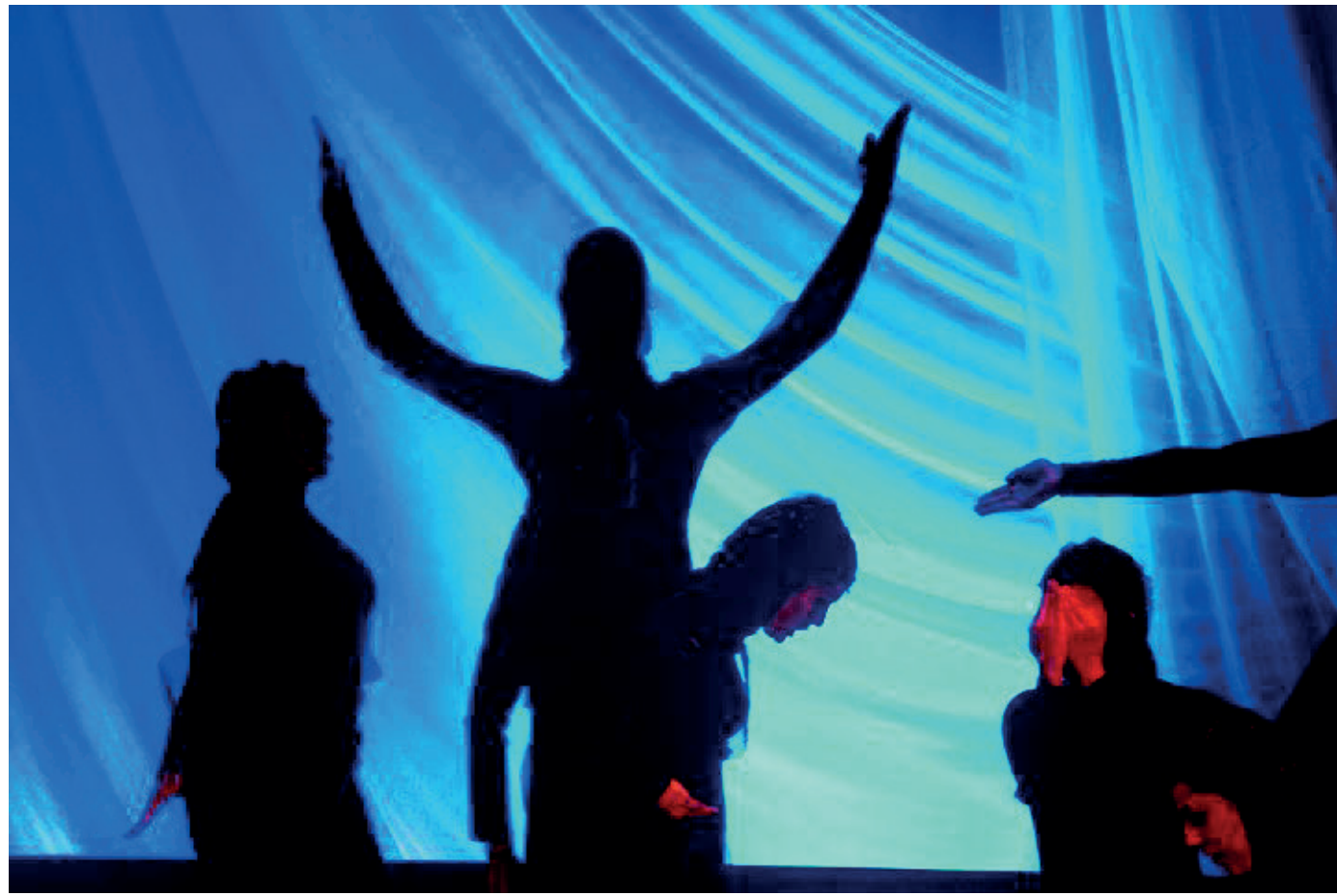

Coro na cena inicial da Ópera Prometheus de Gabriel Fauré encenada em São Paulo em julho de 2011. Teatro Anhembi-Morumbi. Fotografia de Karen Montija

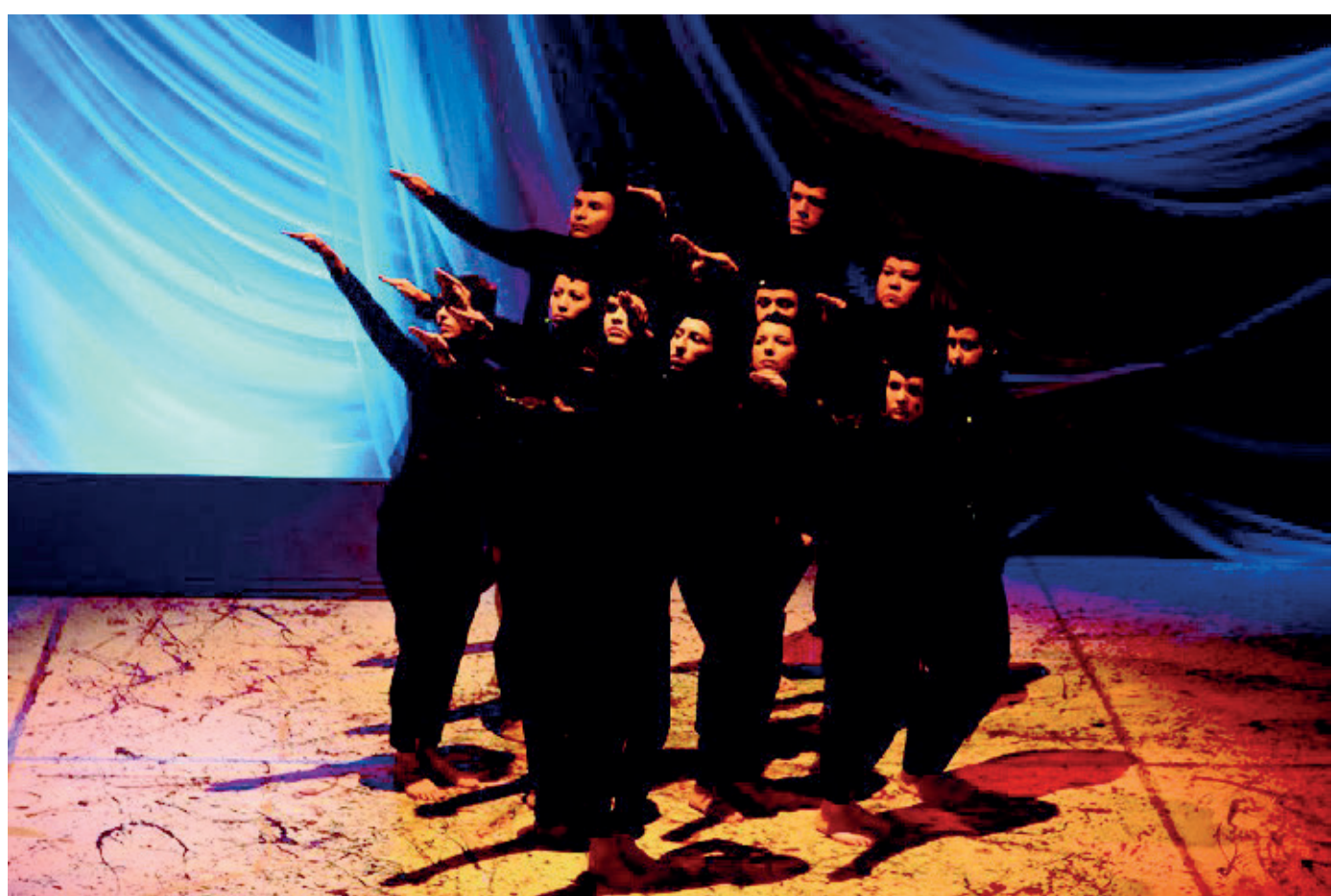

Coro na cena inicial da Ópera Prometheus de Gabriel Fauré encenada em São Paulo em julho de 2011. Teatro Anhembi-Morumbi. Fotografia de Karen Montija

A preparação corporal para Prometheus foi um percurso para que cada artista encontrasse a sua trajetória. Buscamos uma preparação corporal e técnica que foi vivenciada de maneira complexa e cuja coreografia foi organizada pela coreógrafa e pelo encenador de modo que, ao final do processo tenhamos chegado à conclusão definitiva que a ópera, 
assim como declarado por Meyerhold, exige a extensão da ação do ator de tal modo que a melhor forma de prepara-lo para isso seja por meio de dança. Além da ideia de que a dança pode servir a um processo de preparação corporal, para nós ficou claro o potencial dessa dança que subsidiou a ação e a encenação vir para a cena aberta, trazendo como resultado aquilo que denominamos como ópera coreográfica, termo que assumimos, pois consideramos que há profundas identificações conceituais com o que tem sido feito e investigado nas práticas e estudos que revisamos.

A dança, como matéria e forma, processo e produto do nosso trabalho permitiu uma criação de uma proposta artística amplamente articulada, motivada e conduzida pela música e pelos seus sentidos. Partitura corporal e partitura musical e suas métricas, tempos, ritmos, timbres e harmonias foram, ao longo do processo e em cena, absolutamente amalgamadas. A nossa experiência com a ópera coreográfica fincou raízes e estava apenas começando. Firmamos a nossa convicção, realizamos outras experiências e seguimos em busca de novos títulos e outras formas de preparação. A nossa experiência com Prometheus permitiu a materialização de uma encenação desenhada coreograficamente pelos cantores-dançarinos mergulhados nas dinâmicas de ações contínuas e contundentes.

Seguramente trazer à tona a ideia de ópera como forma coreográfica amplia possibilidades cênicas e nos aponta para importantes reflexões teóricas, conceituais, filosóficas e estéticas sobre o fazer artístico no teatro, na música e na ópera concebida como forma teatral e musical.

\section{Referências}

ARMITAGE, M. Martha Graham: the early years. Los Angeles: Da Cappo Paperback, 1978.

BOCCANEGRA, S. A tremendous Tannhäuser led the way in Daniel Barenboim's whirlwind Staatsoper Festival in Berlim. The Guardian (Classical Music: the observer). Disponível em http://www.theguardian.com/music/2014/apr/20/tannhauser-berlin-staatsoper-barenboim-review-simon-boccanegra-domingo (Acessado em 27/03/2016).

CARNEGY, P. Wagner and the Art of the Theatre. Yale: Yale University Press, 2006.

DUDEQUE, N. O Drama Wagneriano e o papel de Adolphe Appia em suas transformações cênicas. Revista Científica /FAP, p.1-16, Curitiba, v.4, n.1, 2009.

HOROSKO, M. Martha Graham: the evolution of her dance, theory and training. Gainesville: University Press of Florida, 2002.

LEVIN,D.(Edit.) Opera throught other eyes. Stanford: Stanford University Press, 1994.

LEVIN,D. Choreographer's Opera? Bodies, Voices, and Meaning in Pina Bausch's Production of Gluck's 'Orpheus and Eurydice’. Vídeo disponível em http://www.vimeoinfo. com/video/45141609/david-levin-choreographers-opera-bodies-voice (Acessado em 02/04/2026).

MORRIS,C. Figaro Dances, Opera Dances: Response to Rebecca Schneider. The Opera Quarterly. pp. 170-175, Vol. 31, No. 3, 2014.

PHILLIPS, E. R Gabriel Fauré: a guide to research (2 $\left.{ }^{\text {nd }} e d.\right)$. London: Routledge, 2011. 
PICON-VALLIN, B. Meyerhold. São Paulo: Perspectiva, 2013.

ROBINSON, H. Love for Three Operas: The Collaboration of Vsevolod Meyerhold and Sergei Prokofiev. The Russian Review. pp. 287-304, Vol. 45, No. 3, 1986.

SCHNEIDER, R. Gesture to Opera: Yinka Shonibare's Un ballo in maschera. The Opera Quarterly. pp. 155-169, Vol. 31, No. 3, 2015.

SCHWARTZ, A. Medium Specificity: Response to Rebecca Schneider. The Opera Quarterly. Vol. 31, No. 3, pp.176-18, 2014.

WAGNER,R. Opera and Drama (translated by W.Ashton Ellis). Nebraska: University of Nebraska Press, 1995.

WALTZ,S. Entwicklung der Choreographischen Oper (The Development of the Choreographic Opera). Disponível em http://www.sashawaltz.de/wp-content/uploads/ Choreographische Oper.pdf (Acessado em 27/03/2016).

YAARI,N. Myth into Dance: Martha Graham's Interpretation of the Classical Tradition. International Journal of the Classical Tradition, pp. 221-242, Vol. 10, No. 2, 2003.

Resumée: Larticle traite de l'idée de l'opéra chorégraphique comme pratique artistique présent dans le champ d'application de la dramaturgie du corps et pour cela, nous avons mis les réflexions soulevées par les chorégraphies des opéras pour plusieurs chorégraphes. En avant nous apportons les positions de l'historien et critique David Levin et quelques positions de Meyerhold sur la mise en scene en lópera. En tant que médiateur de cettes réflexions apporter la expérience dans la conception et la performance de notre version chorégraphique par l'opéra Prometheé (Gabriel Fauré), mis en scène et présenté à São Paulo par une compagnie d’opéra-laboratoire .

Mots-clé: opera; opera choréographique; danse; corp; chant lyrique 